Relations industrielles

Industrial Relations

\title{
Works Committees in France
}

\section{Jean-Pierre Després}

Volume 1, numéro 3, novembre 1945

URI : https://id.erudit.org/iderudit/1024075ar

DOI : https://doi.org/10.7202/1024075ar

Aller au sommaire du numéro

\section{Éditeur(s)}

Département des relations industrielles de l’Université Laval

ISSN

0034-379X (imprimé)

1703-8138 (numérique)

Découvrir la revue

Citer cet article

Després, J.-P. (1945). Works Committees in France. Relations industrielles /

Industrial Relations, 1(3), 5-5. https://doi.org/10.7202/1024075ar

Tous droits réservés (C) Département des relations industrielles de l’Université Laval, 1945
Ce document est protégé par la loi sur le droit d'auteur. L’utilisation des services d'Érudit (y compris la reproduction) est assujettie à sa politique d'utilisation que vous pouvez consulter en ligne.

https://apropos.erudit.org/fr/usagers/politique-dutilisation/ 


\section{WORKS COMMITTEES IN FRANCE}

Among the legitimate aspirations (1) of the working class, participation in the administration of undertakings is one which offers particular interest. Nowadays, workers demand more than suitable wages and working conditions : they wish to play a part within the undertaking, in short, they want to participate in the management of the undertaking. This is a problem of present interest which must be dealt with objectively.

Participation may be of three different kinds : a) participation in the form of an advisory body ; b) participation in the form of supervision; c) participation in the form of co-administration. The two first forms of participation do not affect the essential rights of Capital or of the head of an undertaking, while the third places both workers and shareholders on the same level.

$A$. - In Canada, as well as in Great Britain and the United States, participation of the various categories of the staff in advisory bodies has brought about most satisfactory results, especially as regards economic mobilization. Indeed, the joint production committees have closely associated the workers in the solving of the technical problems of production. Without encroaching upon the field of the syndicates, such boards have filled in a gap which has existed heretofore in industrial relations.

B. - In France, in February 1945, the Provisional Government passed an ordinance instituting " works committees $\%$. In acceding to a demand which has for long been on the programme of various syndicates, the Minister of Labour introduced supervisory participation, thus avoiding participation in the form of co-administration which had been requested by certain groups. The French works committees have a wider field of action and a more explicit part to play than our joint production committees. Their purpose is to ensure effective cooperation within the undertakings between the various factors concerned with production : i.e., management, technical staff and workers. The syndicates name the candidates that are to be members of the committees and, afterwards, their representatives are absolutely independent of the syndicates which have elected them. As to the functions of works committees, such functions are both social and economic.

1. In the social field, the functions of works committees consist in improving working conditions, excluding, however, questions relating to wages, which remain questions to be handled by the syndicates proper. The other social function of works committees consists in assuming or supervising the management of all the social welfare institutions established in the undertakings for the benefit of workers or their families.

2. In the economic field, works committees have advisory functions and are only allowed to look on. In virtue of their advisory functions the works committees will : a) study all the suggestions made by the staff for increasing production and improving the output

(1) "We consider it more advisable, however, in the present condition of human society that, so far as is possible, the workcontract be somewhat modified by a partnership-contract, as is already being done in various ways and with no small advantage to workers and owners. Workers and other employees thus become sharers in ownership or management or participate in some fashion in the profits received ${ }^{\prime}$. - Quadragesimo Anno. of the undertakings and make proposals concerning the application of the suggestions they favour ; b) propose rewards for workers who have, in the committee's opinion, been particularly useful to the undertaking by their initiative or suggestions. c) be constantly informed of questions pertaining to the organization, management and general operation - of the undertaking. At least once a year, management must present a general report on the situation and activities of the undertakings as well as on the plans made for the following period. Moreover, in the case of joint stock companies, or any other kind of company, regularly employing more than 500 workers, the committee must also be informed concerning the profits made and can voice suggestions as regards their use. Finally, in the case of limited liability companies, the management must communicate to the committee, before presenting them to the general meeting of the shareholders, the profit and loss account, the annual balance sheet and the report of the auditors and all other documents which would be submitted to the general meeting of the shareholders. Such are the main provisions of the Ordinance of February 1945.

C. - Participation in the form of co-administration is obviously more complete. In such a case, the representatives of the workers would be on an equal footing with the shareholders' representatives. Coadministration committees would have the power to take decision and give orders, while works committees have but advisory functions and a right to look on. This summary of the question shows the difference which exists between our joint production boards and works committees. While the latter are of a general, permanent and obligatory nature, our Canadian joint production boards are voluntary. Works committees have not only more authority, but employers are unable to avoid their formation. This formula is a compromise between integral co-administration of the undertaking and simple participation in the form of a consultative body. In the social field, the workers have administrative power, and in the economic field, their functions are merely consultative.

Nevertheless, the French ordinance represents a bold reform that many consider as a period of probation imposed upon the workers prior to their admission to administrative committees. All syndical organizations have adopted the following policy : " it is up to the workers to make works committees a success, and they may afterwards aspire to economic co-administration. " An objective analyst recently wrote : "In short, the Ordinance of February 22nd, 1945, has wisely taken foreign experience into account. It has created an institution which is compatible with the capitalist system of present undertakings and has therefore reformed the latter without upsetting them. It contains provisions ensuring the maintenance of management's authority, and others securing peaceable intercourse between the committees and syndical organizations." Such seems to be the general opinion in France.

Jean-Pierre Despres. 